\title{
SPECIFIC CUTTING ENERGY CONSUMPTION IN A CIRCULAR SAW FOR EUCALYPTUS STANDS VM01 AND MN463
}

\author{
Erica Moraes de Souza ${ }^{1}$, José Reinaldo Moreira da Silva², José Tarcísio Lima³ , Alfredo Napoli", \\ Túlio Jardim Raad5, Thiago Gomes Gontijo ${ }^{6}$
}

(received: November 4, 2009; accepted: November 30, 2010)

\begin{abstract}
Modern technologies for continuous carbonization of Eucalyptus sp. require special care in wood cutting procedures. Choosing the right tool, cutting speeds and feed rates is important to manage time and energy consumption, both of which being critical factors in optimizing production. The objective of this work is to examine the influence of machining parameters on the specific cutting energy consumption of Eucalyptus sp. stands MN 463 and VM 01, owned by V\&M Florestal. Tests were performed at the Wood Machining Laboratory of the Federal University of Lavras (DCF/UFLA). Moist logs 1.70m in length were used. The experiment was set up using a 3 × 3 x 4 × 2 factorial design (cutting speed $\mathrm{x}$ feed rate $\mathrm{x}$ number of teeth $\mathrm{x}$ tree stand). Results were subjected to analysis of variance and means were compared by the Tukey test at the $5 \%$ significance level. Greater cutting speeds, lower feed rates and the 40 teeth circular saw consumed more specific energy. Stand MN 463 consumed more specific energy. The combination of cutting speed $46 \mathrm{~m} \cdot \mathrm{s}^{-1}$, feed rate $17 \mathrm{~m} \cdot \mathrm{min}^{-1}$ and 24 teeth circular saw produced better specific energy consumption results for stand MN 463. As for stand VM 01, the combination of cutting speed $46 \mathrm{~m} . \mathrm{s}^{-1}$, feed rate $17 \mathrm{~m} . \mathrm{min}^{-1}$ and 20 teeth circular saw resulted in lower specific energy consumption.
\end{abstract}

Key words: Eucalyptus sp., specific energy, transverse cutting, circular saw, machining.

\section{ENERGIA ESPECÍFICA DE CORTE EM SERRA CIRCULAR PARA OS CLONES DE EUCALYPTUS VM01 E MN463}

RESUMO: Novas tecnologias de carbonização contínua do Eucalyptus sp. requerem cuidados no corte da madeira. A escolha da ferramenta e das velocidades de corte e de avanço influenciam no tempo e no consumo de energia, fatores importantes para otimizar a produção. Objetivou-se, com o presente estudo, verificar a influência dos parâmetros de usinagem no consumo de energia específica de corte da madeira dos clones de Eucalyptus sp., MN 463 e VM 01, da Empresa V\&M Florestal. Os ensaios foram desenvolvidos no Laboratório de Usinagem da Madeira (DCF/UFLA). Foram utilizadas toras úmidas de 1,70 m de comprimento. O delineamento experimental utilizado foi fatorial $3 \times 3 \times 4 \times 2$ (velocidade de corte $x$ velocidade de avanço $x$ número de dentes $x$ clone). Os resultados obtidos foram submetidos à análise de variância e as médias comparadas pelo teste de Tukey a 5\% de significância. Maiores velocidades de corte, menores velocidades de avanço e serra circular de 40 dentes consumiram mais energia específica de corte. O clone MN 463 consumiu maior quantidade de energia específica. A interação entre a velocidade de corte de $46 \mathrm{~m} . \mathrm{s}^{-1}$, a velocidade de avanço de $17 \mathrm{~m} . \mathrm{min}^{-1}$ e a serra circular com 24 dentes apresentou melhores resultados de consumo de energia específica de corte para o clone MN 463. Para o clone VM 01, a interação entre a velocidade de corte de 46 m.s. ${ }^{-1}$, a velocidade de avanço de 17 m.minn e a serra circular com 20 dentes apresentou menor consumo de energia específica de corte.

Palavras-chave: Eucalyptus sp., energia específica, corte transversal, serra circular, usinagem.

\section{INTRODUCTION}

Nonnative origin wood charcoal plays an important part in Brazilian economy, in particular the economy of
Minas Gerais state, the main producing and consuming state in Brazil. Most Eucalyptus stands there are intended for charcoal production for use in metallurgy. According to Minas Gerais Silviculture Association-AMS (2009),

\footnotetext{
${ }^{1}$ Forest Engineer, Professor M.Sc. in Wood Science and Technology - Departamento de Ciências Florestais/DCF - Universidade Federal de Lavras/UFLACx.P. 3037 - 37200-000 - Lavras, MG, Brasil - ericafloresta@yahoo.com.br

${ }^{2}$ Forest Engineer, Professor Ph.D. in Forest Engineering - Departamento de Ciências Florestais/DCF - Universidade Federal de Lavras/UFLA-Cx.P. 3037 37200-000 - Lavras, MG, Brasil - jreinaldo@dcf.ufla.br

${ }^{3}$ Forest Engineer, Ph.D. in Forest Sciences - Departamento de Ciências Florestais/DCF - Universidade Federal de Lavras/UFLA - Cx.P. 3037 37200-000 - Lavras, MG, Brasil - jtlima@dcf.ufla.br

${ }^{4}$ Materials Scientist, Ph.D. in Energetic Systems - CIRAD - BIOS Department - TA A-39 - Genetic diversity and breeding of forest species 73 rue Jean-François Breton - 34398 - Montpellier, France - alfredo.napoli@cirad.fr

${ }^{5}$ Mechanical Engineer, Ph.D. in Mechanical Engineering - V\&M Florestal LTDA - Fazenda Itapoã, s/n. Zona Rural - 35774-000 - Paraopeba, MG, Brasil - tulraad@vmtubes.com.br

${ }^{6}$ Forest Engineer - Departamento de Ciências Florestais/DCF - Universidade Federal de Lavras/UFLA - Cx.P. 3037 - $37200-000$ - Lavras, MG, Brasil -tggfloresta@yahoo.com.br
} 
in 2008 the total area covered by Eucapyptus stands in the state intended for pig iron production was 65,587 ha, and the total consumption of wood charcoal by the steel industry was 20.9 million meters. Other than the steel industry, charcoal is also a substitute for fuel oil in boilers and combustion furnaces in the cement and other primary material industry (TRUGILHO et al., 2001).

Where charcoal is produced in traditional ovens, wood is cut to approximately $3.60 \mathrm{~m}$ in length and tools include chainsaws or other forest equipment. Where continuous carbonization is used, log pieces are approximately $30 \mathrm{~cm}$ in length and sections are processed using circular saws. Wood processing operations should be done so as to spare equipment of excessive wear and tear, damage or destruction, ultimately seeking to reduce maintenance and replacement costs (BROWN; BETHEL, 1975).

Néri et al. (1999) argued that cutting force requirements have considerable importance in the design of cutting tool geometry and also in the power demanded from equipment. Cutting forces may vary depending on the sharpness and type of tool being used, on the species and also on grain orientation and cut direction.

Specific cutting energy consumption is defined as the relationship between net cutting energy consumption and volume of removed material. Meyer (1926), as cited by Kollmann and Cotê Júnior (1968), found that higher cutting speeds are associated with reduced cutting energy efficiency. Specific energy along with specific force allows comparison and assessment of cutting tool efficiency (LUBKIN, 1957, as cited by KOLLMANN; COTÊ JÚNIOR, 1968).

Ersoy and Atici (2004) argued that from specific cutting energy data one can estimate the power required, noting however that motor efficiency as well as friction and inertia effects are also factors to be considered.

Given the need to boost production and reduce costs, the charcoal industry is proposing to use variable frequency drives, operated at different speeds (SIMÃO; ALMEIDA NETO, 2002). Campana et al. (2000) argued that variable frequency drives are effective tools to correct load indices, performance and power factors found lower than nominal, and to prevent unnecessary burden on electric motors, ultimately translating as reduced energy consumption. The use of variable frequency drives in irrigation has provided satisfactory results, helping reduce power consumption and allowing energy savings (HANSON et al., 1996).

Through combined efforts of UFLA, CIRAD/ France and V\&M Florestal, the objective of this study is to optimize both production and quality of Eucalyptus charcoal for the steel industry, by studying the influence of cutting speeds, feed rates, number and geometry of circular saw teeth on specific cutting energy consumption regarding Eucalyptus sp. stands MN 463 and VM 01.

\section{MATERIAL AND METHODS}

Logs $1.70 \mathrm{~m}$ in length and 7 to $11 \mathrm{~cm}$ in diameter were used from stands MN 463 (a natural Eucalyptus urophylla hybrid) and VM 01 (Eucalyptus camaldulensis x Eucalyptus urophylla), at age 8 years, located in the municipality of Paraopeba/MG and owned by V\&M Florestal. Newly felled logs were selected (unseasoned wood). The average basic wood density was 0.514 and 0.574 g.cm ${ }^{-3}$, for stands MN 463 and VM 01 respectively. Tests were performed at the Wood Machining Laboratory of the Department of Forest Sciences, Federal University of Lavras (DCF/UFLA).

Measurements were taken of feed rates and rotation frequency of the circular saw used by the production unit of V\&M Florestal, and cutting speed was then calculated. With these data at hand, an automatic table motion system was devised for the moving circular saw, at the Wood Machining Laboratory (DCF/UFLA) (Figure 1), controlled by a variable frequency drive that stored electrical parameters. The variable frequency drive used was a CFW08 (WEG) model, equipped with a serial communication interface (KSD CFW08), SuperDrive ${ }^{\circledR}$ software.

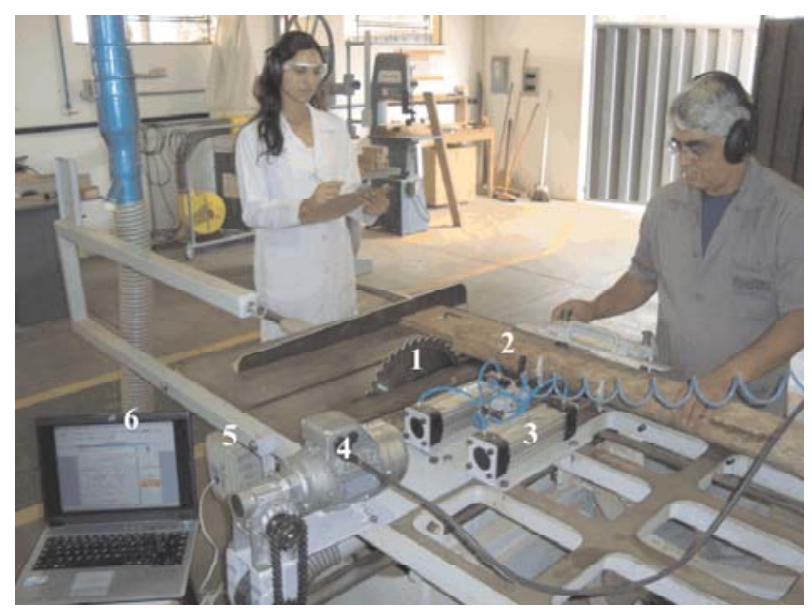

Figure 1 - Feed rate and cutting speed controlled moving circular saw (DCF/UFLA). 1) circular saw, 2) log section, 3) pneumatic pistons, 4) feed motor, 5) variable frequency drive and 6) computer.

Figura 1 - Serra circular de carrinho (DCF/UFLA), com controle de velocidade de avanço e de corte. 1) serra circular, 2) tora, 3) pistões pneumáticos, 4) motor de avanço, 5) inversor de frequência e 6) computador.

Cerne, Lavras, v. 17, n. 1, p. 109-115, jan./mar. 2011 
Four parameters were acquired simultaneously during the cutting operation, namely: value proportional to rotation frequency $\left(\mathrm{min}^{-1}=\mathrm{RPM}\right)$, motor output current (Amperes), motor output voltage (Volts) and motor torque (\%). Parameter acquisition time was 250 milliseconds, according to the work of Oliveira et al. (2008). To determine specific energy, rotation frequency and torque were used.

Once data was collected by the software, log cutting intervals were identified by selecting abruptly ascending/descending torque values alternating with reduced, relatively constant torque ranges, the latter being discarded.

Machining parameters being assessed are described in Table 1. The teeth geometry used was alternate cutting edges. However, for the 40 teeth saw, which is similar to the saw used by V\&M Florestal, two successive alternating teeth were used, one trapezoidal and one flat.

Table 1 - Levels and specifications of machining parameters used.

Tabela 1 - Níveis e especificações dos parâmetros de usinagem adotados.

\begin{tabular}{lccccc}
\hline \multicolumn{1}{c}{ Factors } & Levels & \multicolumn{4}{c}{ Specifications } \\
\hline Cutting speed $\left({\left.\mathrm{m} . \mathrm{s}^{-1}\right)}^{3}\right.$ & 46 & $58^{*}$ & 70 & \\
Feed rate $\left(\mathrm{m} \cdot \mathrm{min}^{-1}\right)$ & 3 & 7 & $12^{*}$ & 17 & \\
Number of teeth & 4 & 20 & 24 & $40^{*}$ & 48 \\
Tree stand & 2 & MN 463 & VM 01 & & \\
\hline Treatments total & 72 & \multicolumn{5}{c}{} \\
\hline
\end{tabular}

*Machining conditions at V\&M Florestal

To calculate the specific energy consumption of each treatment, Equations 1, 2 and 3 were used.

$$
\text { Power }=\frac{T \times n \times 0.0014 \times 736}{1000}
$$

Power = cutting power $(\mathrm{kW})$;

$T$ = torque (kgf.m);

$n=\operatorname{rotation}\left(\mathrm{min}^{-1}=\mathrm{rpm}\right)$.

$E=\left(\frac{\text { Power } \times D}{V f}\right) \times 60$

$E=$ energy $(\mathrm{kJ})$;

Power = cutting power $(\mathrm{kW})$;

$D=\log$ diameter $(\mathrm{m})$;

$V f=$ feed rate $\left(\mathrm{m} \cdot \mathrm{min}^{-1}\right)$.
$E s=\frac{4 \times E}{\pi \times D^{2} \times k}$

$E s$ = specific energy $\left(\mathrm{kJ} . \mathrm{cm}^{-3}\right)$;

$E=$ energy $(\mathrm{kJ})$;

$D=$ average log diameter $(\mathrm{cm})$;

$k=$ tooth thickness $(\mathrm{cm})$.

The experiment was set up using a completely randomized design with a $3 \times 3 \times 4 \times 2$ factorial arrangement (cutting speed $\mathrm{x}$ feed rate $\mathrm{x}$ number of teeth $\mathrm{x}$ tree stand), with 20 replicates. Data were subjected to analysis of variance and means were compared by the Tukey test at the 5\% significance level.

\section{RESULTS AND DISCUSSION}

Results showed that a cutting speed of 70 m.s. produced a higher overall mean $\left(4.84 \times 10^{-2} \mathrm{~kJ}_{\mathrm{cm}}{ }^{-3}\right)$ of specific energy consumption whereas a cutting speed of $58 \mathrm{~m} . \mathrm{s}^{-1}$ produced a lower mean $\left(4.16 \times 10^{-2}{\mathrm{~kJ} . \mathrm{cm}^{-3}}^{-3}\right.$. In both stands there was a tendency for the specific cutting energy consumption to decrease with increasing feed rates. With increasing cutting speeds, on the other hand, there was a tendency for specific energy consumption to increase. High cutting speeds are associated with higher rotation frequency values, consequently increasing the cutting power requirements (Equations 1, 2 and 3). In a study on specific energy consumption at different cutting speeds for aluminum and steel, Rodrigues and Coelho (2007) found that specific energy consumption decreased with increasing cutting speeds. The authors reported that facilitated metal ductility and chip formation was due to the temperature rise during the cutting procedure. Owing to its insulating properties, wood does not favor substantial temperature rises.

A feed rate of $7 \mathrm{~m} \cdot \mathrm{min}^{-1}$ produced the highest average value of specific cutting energy consumption, whereas a feed rate of $17 \mathrm{~m} . \mathrm{min}^{-1}$ produced the lowest

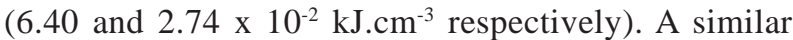
pattern was observed in steel machining, as described by Diniz et al. (2000). According to these authors, during the cutting process some of the removed material (chip fragment) is driven between the flank face of the tool and the machined surface (through the clearance angle), and this generates lateral chip flow. The slower the flow, the more friction is created between the cutting tool and the workpiece surface, consequently increasing energy consumption.

Cerne, Lavras, v. 17, n. 1, p. 109-115, jan./mar. 2011 
The analysis of variance (Table 2) showed that main effects and their relevant interactions were significant, and factors are interdependent. The breakdown of cutting speed at each level of feed rate, number of teeth and tree stand was done by multiple comparisons at the $5 \%$ significance level, by the Tukey test.

Table 2 - Analysis of variance summary for specific cutting energy consumption concerning Eucalyptus sp. stands MN 463 and VM 01, as a function of cutting speed, feed rate, number of teeth, stand and respective double, triple and quadruple interactions.

Tabela 2 - Resumo da análise de variância para o consumo da energia específica de corte da madeira dos clones de Eucalyptus sp. MN 463 e VM 01, em função das velocidades de corte, velocidade de avanço, número de dente, clone e suas respectivas interações duplas, triplas e quádruplas.

\begin{tabular}{lcc}
\hline Source & $\begin{array}{c}\text { Degree of } \\
\text { Freedom }\end{array}$ & Mean Square \\
\hline Cutting speed (Vc) & 2 & $0.006320^{*}$ \\
Feed rate (Vf) & 2 & $0.163665^{*}$ \\
Number of teeth (Z) & 3 & $0.024844^{*}$ \\
Tree stand & 1 & $0.003921^{*}$ \\
Vc x Vf & 4 & $0.006710^{*}$ \\
Vc x Z & 6 & $0.004246^{*}$ \\
Vc x Tree stand & 2 & $0.016456^{*}$ \\
Vf x Z & 6 & $0.002986^{*}$ \\
Vf x Tree stand & 2 & $0.000153^{*}$ \\
Z x Tree stand & 3 & $0.006511^{*}$ \\
Vc x Vf x Z & 12 & $0.002190^{*}$ \\
Vc x Vf x Tree stand & 4 & $0.008087^{*}$ \\
Vf x Z x Tree stand & 6 & $0.001025^{*}$ \\
Vc x Vf x Z x Tree stand & 12 & $0.002823^{*}$ \\
\hline Error & 1374 & 0.000038 \\
\hline Corrected Total & 1799 & \\
\hline
\end{tabular}

* - significant at the $5 \%$ significance level; overall mean $=$ 0.044238 ; coefficient of variation $=13.98 \%$.

There was a tendency for specific cutting energy consumption to increase as a function of increasing number of teeth, in both stands (Figures 2, 3 and 4). Overall, the 40 teeth and 48 teeth circular saws produced higher values of specific cutting energy consumption (5.11 and $5.16 \mathrm{x}$ $10^{-2}{\mathrm{~kJ} . \mathrm{cm}^{-3}}$ respectively), not differing statistically. On average, the 24 teeth circular saw produced lower values of specific energy consumption (3.57 x $\left.10^{-2} \mathrm{~kJ} \mathrm{~cm}^{-3}\right)$. A larger number of teeth could infer wood scraping rather than cutting when interacting with the cutting speeds and feed rates being studied, consequently causing more energy consumption.

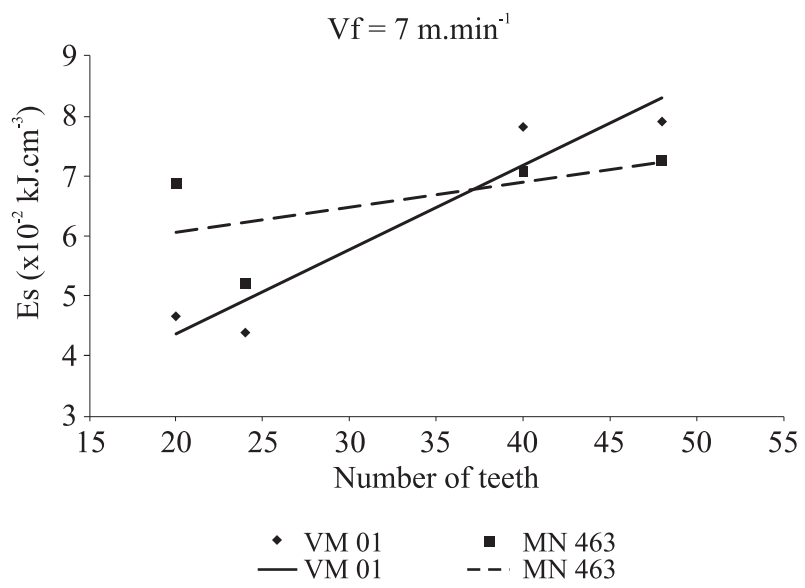

Figure 2 - Specific energy consumption tendency for Eucalyptus sp. stands MN 463 and VM 01 as a function of number of teeth, with a feed rate of $7 \mathrm{~m} \cdot \mathrm{min}^{-1}$.

Figura 2 - Tendência do consumo de energia específica de corte para os clones de Eucalyptus sp. MN 463 e VM 01 em função do número de dentes para a velocidade de avanço de 7 m. $\mathrm{min}^{-1}$.

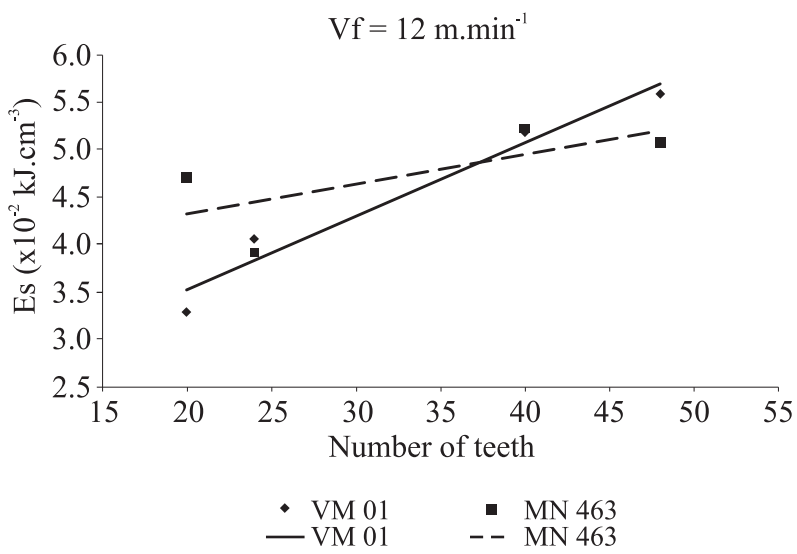

Figure 3 - Specific energy consumption tendency for Eucalyptus sp. stands MN 463 and VM 01 as a function of number of teeth, with a feed rate of $12 \mathrm{~m} \cdot \mathrm{min}^{-1}$.

Figura 3 - Tendência do consumo de energia específica de corte para os clones de Eucalyptus sp. MN 463 e VM 01 em função do número de dentes para a velocidade de avanço de $12 \mathrm{~m} \cdot \mathrm{min}^{-1}$.

Cerne, Lavras, v. 17, n. 1, p. 109-115, jan./mar. 2011 


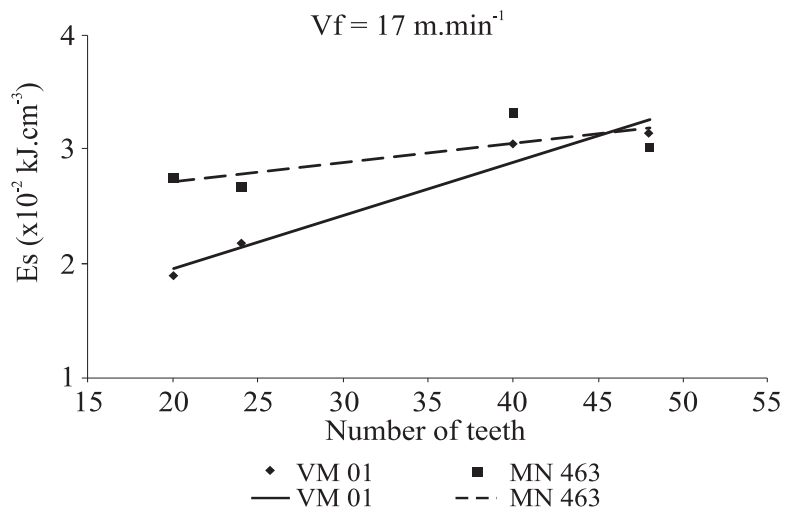

Figure 4-Specific energy consumption tendency for Eucalyptus sp. stands MN 463 and VM 01 as a function of number of teeth, with a feed rate of $17 \mathrm{~m} \cdot \mathrm{min}^{-1}$.

Figura 4 - Tendência do consumo de energia específica de corte para os clones de Eucalyptus sp. MN 463 e VM 01 em função do número de dentes para a velocidade de avanço de $17 \mathrm{~m} . \mathrm{min}^{-1}$.

When cutting the wood from stand MN 463, the 40 teeth and the 48 teeth circular saws produced overall higher mean values of specific energy consumption, 5.04 and $4.95 \times 10^{-2} \mathrm{~kJ}_{\mathrm{cm}} \mathrm{cm}^{-3}$ respectively, though these values did not differ statistically. The 24 alternate teeth circular saw produced the lowest mean value of specific cutting energy consumption, $3.76 \times 10^{-2} \mathrm{~kJ}_{\mathrm{cm}} \mathrm{cm}^{-3}$.

With wood from stand MN 463, using a feed rate of 7 m.min ${ }^{-1}$, a 40 teeth circular saw (alternate flat and trapezoidal teeth) and a cutting speed of $70 \mathrm{~m} \cdot \mathrm{s}^{-1}$ resulted in the highest value of specific cutting energy consumption, $9.02 \times 10^{-2} \mathrm{~kJ}$. $\mathrm{cm}^{-3}$. The lowest value of specific energy consumption $(1.88 \mathrm{x}$ $10^{-2} \mathrm{~kJ} \mathrm{~cm}^{-3}$ ) was produced when using a feed rate of $17 \mathrm{~m} . \mathrm{min}^{-1}$, a 24 alternate teeth circular saw and a cutting speed of $46 \mathrm{~m} \cdot \mathrm{s}^{-1}$.

With wood from stand VM 01, the 48 teeth saw produced a higher mean value of specific cutting energy consumption $\left(5.38 \times 10^{-1} \mathrm{~kJ} \mathrm{~cm}^{-3}\right)$. The 20 alternate teeth saw produced a lower mean value of energy consumption

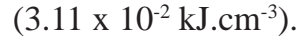

The highest value of specific cutting energy consumption $\left(11.52 \times 10^{-2} \mathrm{~kJ}_{\mathrm{cm}} \mathrm{cm}^{-3}\right)$ for stand VM 01 was observed when using a feed rate of $7 \mathrm{~m} \cdot \mathrm{min}^{-1}$, a 48 alternate teeth circular saw and a cutting speed of $58 \mathrm{~m} . \mathrm{s}^{-1}$. The use of a feed rate of $17 \mathrm{~m} . \mathrm{min}^{-1}$, a 20 alternate teeth saw and a speed of $46 \mathrm{~m} . \mathrm{s}^{-1}$ produced the lowest value of specific energy consumption, $1.10 \times 10^{-2} \mathrm{~kJ}_{\mathrm{cm}} \mathrm{cm}^{-3}$.

It was noted that, regardless of stand density, cutting speed and feed rate, there was an increase in specific cutting energy consumption with increasing number of teeth being used. Overall analysis of data (Figures 5, 6 and 7) revealed that stand MN $463\left(0.514\right.$ g.cm $\left.{ }^{-3}\right)$ showed more specific energy consumption in comparison to stand VM 01 (0.574 g. $\mathrm{cm}^{-3}$ ), with mean values of specific energy consumption at 4.59 and $4.26 \times 10^{-2} \mathrm{~kJ} \mathrm{~cm}^{-3}$ respectively. The stand with higher numerical value of density showed less specific cutting energy consumption, disputing literature in general. However, analyses of variance of moisture (Table 3) and basic density (Table 4) of logs from stands MN 463 and VM 01 reveal statistical similarity for these variables, ruling out the possibility of inferring that the wood from stand VM 01 is denser.

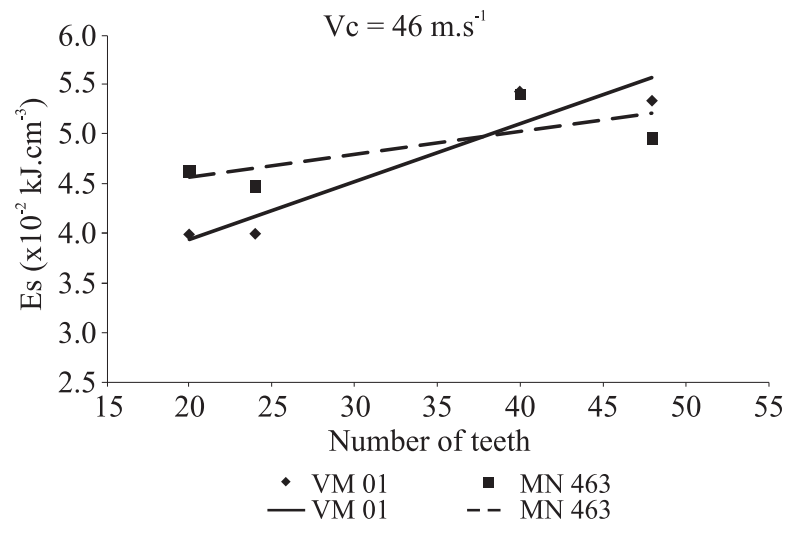

Figure 5 - Specific energy consumption tendency for Eucalyptus sp. stands MN 463 and VM 01 as a function of number of teeth, for a cutting speed of $46 \mathrm{~m} \cdot \mathrm{s}^{-1}$.

Figura 5-Tendência do consumo de energia específica de corte para os clones de Eucalyptus sp. MN 463 e VM 01 em função do número de dentes para a velocidade de corte de $46 \mathrm{~m} \cdot \mathrm{s}^{-1}$.

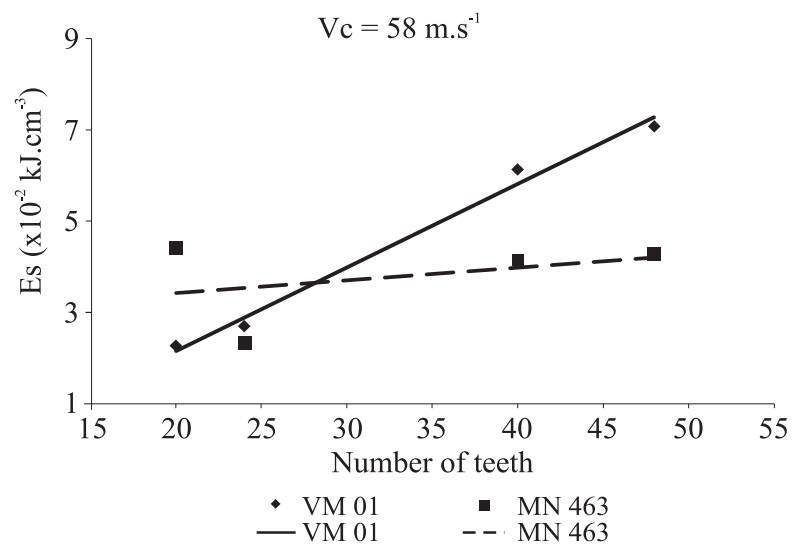

Figure 6 - Specific energy consumption tendency for Eucalyptus sp. stands MN 463 and VM 01 as a function of number of teeth, for a cutting speed of $58 \mathrm{~m} \cdot \mathrm{s}^{-1}$.

Figura 6 - Tendência do consumo de energia específica de corte para os clones de Eucalyptus sp. MN 463 e VM 01 em função do número de dentes para a velocidade de corte de $58 \mathrm{~m} . \mathrm{s}^{-1}$.

Cerne, Lavras, v. 17, n. 1, p. 109-115, jan./mar. 2011 


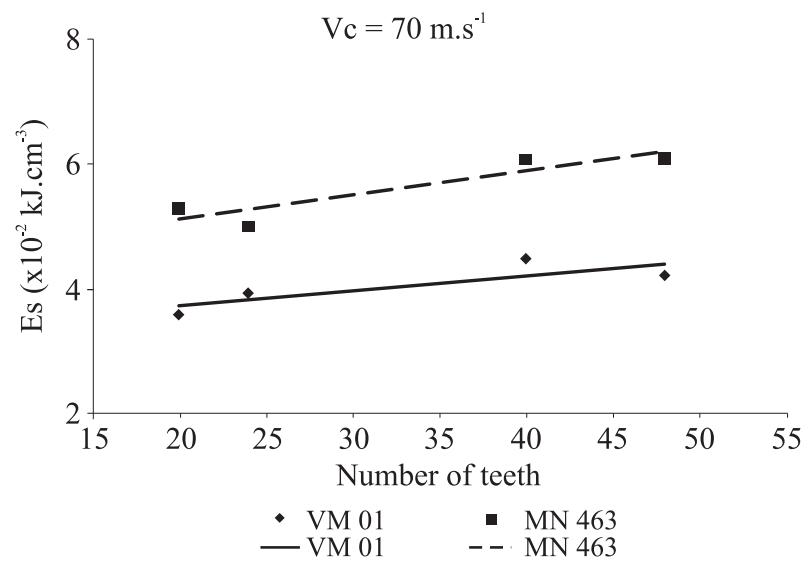

Figure 7 - Specific cutting energy consumption tendency for Eucalyptus sp. stands MN 463 and VM 01 as a function of number of teeth, for a cutting speed of $70 \mathrm{~m} \cdot \mathrm{s}^{-1}$.

Figura 7-Tendência do consumo de energia específica de corte para os clones de Eucalyptus sp. MN 463 e VM 01 em função do número de dentes para a velocidade de corte de $70 \mathrm{~m} \cdot \mathrm{s}^{-1}$.

Table 3 - Analysis of variance summary for unseasoned woods from Eucalyptus sp. stands MN 463 and VM 01, as a function of moisture.

Tabela 3 - Resumo da análise de variância das madeiras denominadas verdes, para os clones de Eucalyptus sp. MN 463 e VM 01, em função da umidade.

\begin{tabular}{lcc}
\hline Source & $\begin{array}{c}\text { Degree of } \\
\text { Freedom }\end{array}$ & Mean Square \\
\hline Tree stands & 1 & $229.336806^{\text {n.s }}$ \\
Error & 70 & 141.709853 \\
\hline Corrected Total & 71 & \\
\hline
\end{tabular}

Overall mean $=73.0930556$; Coefficient of variation $=16.29 \%$. ns - nonsignificant at the 5\% significance level.

Table 4 - Analysis of variance summary for wood from Eucalyptus sp. stands MN 463 and VM 01, as a function of basic density.

Tabela 4 - Resumo da análise de variância da madeira dos clones de Eucalyptus sp. MN463 e VM 01, em função da densidade básica.

\begin{tabular}{lcc}
\hline Source & $\begin{array}{c}\text { Degree of } \\
\text { Freedom }\end{array}$ & Mean Square \\
\hline Tree stands & 1 & $0.375000^{\text {ns }}$ \\
Error & 4 & 0.125000 \\
\hline Corrected Total & 5 & \\
\hline
\end{tabular}

Overall mean $=0.7500000$; Coefficient of variation $=47.14 \%$. ns - nonsignificant at the $5 \%$ significance level.

Cerne, Lavras, v. 17, n. 1, p. 109-115, jan./mar. 2011
These values correspond to an average increase of $7.7 \%$ in energy consumption to cut wood from stand MN 463.

\section{CONCLUSIONS}

From analyses performed on stands MN 463 and VM 01, including cutting speeds, feed rates, number of teeth and teeth geometry of circular saws, the following conclusions were drawn:

- higher cutting speeds and lower feed rates demanded more specific cutting energy consumption;

- the 40 teeth circular saw with alternate trapezoidal and flat teeth demanded more specific cutting energy consumption, thus being unsuitable for the cut in question;

- the interaction of a cutting speed of $46 \mathrm{~m} . \mathrm{s}^{-1}$, a feed rate of $17 \mathrm{~m} \cdot \mathrm{min}^{-1}$ and a 24 alternate teeth circular saw showed better results of specific cutting energy consumption for unseasoned wood from stand MN 463;

- the interaction of a cutting speed of $46 \mathrm{~m} \cdot \mathrm{s}^{-1}$, a feed rate of $17 \mathrm{~m} \cdot \mathrm{min}^{-1}$ and a 20 alternate teeth circular saw demanded less specific cutting energy consumption for unseasoned wood from stand VM 01;

- unseasoned wood from stand MN463 demanded more specific cutting energy in comparison to unseasoned wood from stand VM 01, despite them being statistically similar.

\section{ACKNOWLEDGMENTS}

The authors wish to thank V\&M Florestal, Kampmann do Brasil Ltda. and CIRAD/France.

\section{REFERENCES}

\section{ASSOCIAÇÃO MINEIRA DE SILVICULTURA. Anuário} estatístico 2009. Disponível em <http://www.silviminas.com. br/>. Acesso em: 9 jul. 2009.

BROWN, N. C.; BETHEL, J. S. La industria maderera. México: Limusa, 1975. 388 p.

\section{CAMPANA, S. Racionalização do uso da energia elétrica} em sistemas de irrigação tipos pivô central e aspersão convencional. 2000. 108 p. Dissertação (Mestrado em Engenharia Agrícola) - Universidade Federal de Viçosa, Viçosa, 2000.

DINIZ, A. E.; MARCONDES, F. C.; COPPINI, N. L. Tecnologia da usinagem dos materiais. 2. ed. São Paulo: Artliber, 2000. 244 p. 
ERSOY, A.; ATICI, U. Performance characteristics of circular diamond saws in cutting of different type of rocks. Diamond and Related Materials, v. 13, p. 22-37, Jan. 2004.

HANSON, B.; WEIGAND, C.; ORLOFF, S. Performance of electric irrigation pumping plants using variable frequency drives. Journal of Irrigation and Drainage Engineering, New York, v. 122, n. 3, p. 179-82, May/June 1996.

KOLLMANN, F. F. P.; CÔTE JÚNIOR, W. A. Principles of wood science and technology. New York: [s.n.], 1968. v. 1, $592 \mathrm{p}$.

NÉRI, A. C.; GONÇALVES, R.; HERNANDEZ, R. E. Forças de corte ortogonal 90-0 em três espécies de madeira de eucalipto. Revista Brasileira de Engenharia Agrícola e Ambiental, Campina Grande, v. 3, n. 2, p. 239-244, 1999.
OLIVEIRA, G. M. V.; SILVA, J. R. M.; MARTINS, M. Medição de ângulos básicos de corte em serras de disco de processamento da madeira e derivados. In: ENCONTRO BRASILEIRO EM MADEIRA E ESTRUTURAS DE MADEIRA-EBRAMEM, 11., 2008, Londrina. Anais... Londrina, 2008. CD-ROM.

RODRIGUES, A. R.; COELHO, R. T. Influence of the tool edge geometry on specific cutting energy at high-speed cutting. Journal of the Brazilian Society of Mechanical Sciences and Engineering, v. 29, p. 279-283, 2007.

SIMÃO, E. B.; ALMEIDA NETO, M. F. Rendimento do conjunto inversor/motor de indução sob diferentes condições de carga. Goiânia: UFG, 2002. Projeto final de curso.

TRUGILHO, P. F.; LIMA, J. T.; MORI, F. A.; LINO, A. L. Avaliação de clones de Eucalyptus para produção de carvão vegetal. Cerne, Lavras, v. 7, n. 2, p. 104-114, 2001. 